\title{
ASUPAN ZAT GIZI DAN HUBUNGANNYA DENGAN STATUS GIZI PADA REMAJA PUTRI
}

\author{
Nuryani $^{*}$ \\ 1. Program Studi Ilmu Gizi Fakultas Kesehatan Masyarakat, Universitas Gorontalo, Gorontalo- \\ Indonesia
}

*Korespondensi: Nuryani | Universitas Gorontalo | nuryanigz@ gmail.com

\begin{abstract}
Abstrak
Pendahuluan: Remaja merupakan kelompok rentang mengalami permasalahan gizi yang berdampak terhadap kualitas sumber daya manusia. Penelitian ini bertujuan untuk mengkaji status gizi dan asupan zat gizi pada remaja putri.

Metode: Jenis penelitian adalah cross sectional study dengan jumlah sampel 50 remaja yang dilakukan secara accidental sampling. Analisis data dilakukan secara univariat dan bivariat.

Hasil: Hasil penelitian menunjukkan indeks massa tubuh 22,39 \pm 4,46 dan lingkar lengan atas 26,35 $\pm 3,51 \mathrm{~cm}$, terdapat 20\% remaja mengalami kekurangan energy kronik dan 20\% obesitas. Gambaran asupan zat gizi menunjukkan asupan vitamin C 3,87 $\pm 8,10 \mathrm{mg}$ (96\% kurang), vitamin E 1,22 $\pm 0,89 \mathrm{mg}$, zat besi 3,59 $\pm 2,84 \mathrm{mg}$, seng 1,22 $\pm 1,15 \mathrm{mg}$ (100\% kurang) sementara asupan kalsium 172,93 \pm 302,02 mg (98\% kurang).

Kesimpulan: Analisis bivariate menunjukkan tidak terdapat hubungan antara asupan zat gizi dengan status gizi pada remaja. Disimpulkan bahwa remaja putri masih mengkosumsi zat gizi di bawah angka kecukupan gizi yang dianjurkan.
\end{abstract}

Kata Kunci : Remaja putri, Status gizi, Zat gizi.

Diterima 24 Oktober 2018; Accepted 30 Desember 2018

\section{PENDAHULUAN}

Peningkatan kualitas sumber daya manusia mesti didukung oleh status gizi dan kesehatan yang optimal pada kelompok usia reproduktif, termasuk remaja. Remaja putri lebih rentang mengalami masalah gizi salah dibandingkan wanita usia reproduktif lainnya. Hal ini dapat disebabkan karena keadaan psikologis yang belum stabil, peningkatan kebutuhan zat gizi dan buruknya pengetahuan tentang gizi (Venkaiah et al., 2002 dan Bhandari et al., 2016). Menurut Arisman (2004) terdapat tiga alasan mengapa remaja dikategorikan rentan mengalami masalah gizi. Pertama, percepatan pertumbuhan dan perkembangan tubuh memerlukan energi dan zat gizi yang lebih banyak. Kedua, perubahan gaya hidup dan kebiasaan konsumsi pangan menuntut penyesuaian makanan energi dan zat gizi. Ketiga, kehamilan, keikutsertaan dalam olahraga, kecanduan alkohol dan obat.

Masalah gizi pada remaja akan memberikan sejumlah konsekuensi dalam sejumlah aspek kehidupan. Stunting pada remaja putri akan meningkatkan risiko gangguan perinatal, hal ini sangat berkaitan dengan perbaikan gizi remaja putri sebelum mengalami kehamilan (USAID, 2015). Kehamialn pada usia remaja akan berdampak pada disproporsi chepalopelvic yang menjadi salah satu penyulit persalinan (Venkaiah et al., 2002). Obesitas pada remaja akan berdampak pada risiko penyakit kardiovaskular pada usia dewasa. Anemia juga merupakan permasalahan gizi yang akan mengganggu pertumbuhan dan perkembangan remaja (WHO, 2006).

Kebiasaan makan dan pola konsumsi banyak dikaitkan dengan permasalahan gizi yang muncul pada kelompok remaja. Penelitian di Makassar pada remaja putri mendapatkan hubungan yang signifikan antara asupan energy, protein, lemak, karbohidrat, zat besi dan seng dengan status gizi berdasarkan indikator indeks massa tubuh dan lingkar lengan atas (Muchlisa dkk, 2013). Penelitian lainnya yang dilakukan pada di Maros, mendapatkan bahwa remaja cenderung mengkonsumsi energy, zat gizi makro dan zat gizi mikro lebih rendah dibandingkan dengan angka kecukupan gizi (AKG) yang direkomendasikan bagi remaja (Fanny dkk, 2010). Penelitian pada remaja di India dan Bangladesh mendapatkan bahwa asupan kurang hampir seluruh zat gizi, terutama zat besi, kalsium, vitamin A dan vitamin $\mathrm{C}$, penyebab utamanya adalah pendidikan orang tua dan pendapatan keluarga rendah (WHO, 2006).

Remaja merupakan kelompok usia yang rentang mengalami permasalahan gizi. Berdasarkan data Riskesdas (2013) secara nasional remaja umur 16 - 18 tahun dengan status gizi pendek adalah 31,4\%, 
sementara provinsi Gorontalo sebanyak 49,7\%, berdasarkan indikator indeks massa tubuh menurut umur remaja dengan status gizi kurus secara nasional adalah 9,4\%, sementara provinsi Gorontalo adalah 7,8\%. Prevalensi berat badan lebih dan obesitas secara nasional adalah 7,3\%, sementara provinsi Gorontalo $10,3 \%$. Prevalensi obesitas remaja di provinsi Gorontalo lebih tinggi dibandingkan prevalensi nasional.

Remaja putri merupakan salah satu kelompok yang rentang mengalami masalah gizi, sehingga upaya pengkajian lanjut menjadi penting dilakukan mengingat besarnya dampak yang dapat diakibatkan dari masalah gizi tersebut. Nilai kebaruan dari penelitian ini adalah dilakukan pengukuran status gizi dengan indikator berbeda yakni indeks massa tubuh untuk mengidentifikasi kejadian berat badan kurang dan obesitas serta indikator ligkar lengan atas untuk mengidentifikasi kejadian kekurangan energy kronis. Di kabupaten Gorontalo masih terbatas penelitian terkait gizi pada remaja, sehingga penelitian ini bertujuan untuk menilai hubungan antara asupan zat gizi dengan status gizi pada remaja putri.

\section{METODE}

Desain penelitian adalah cross sectional study untuk menilai hubungan antara asupan zat gizi dengan status gizi pada remaja. Lokasi penelitian dilakukan di Fakultas Kesehatan Masyarakat Universitas Gorotalo, Kabupaten Gorontalo. Penelitian dilaksanakan pada bulan Oktober - Desember 2016.

Populasi dalam penelitian ini adalah seluruh mahasiswa putri di Fakultas Kesehatan Masyarakat Universitas Gorontalo. Jumlah sampel adalah sebanyak 50 orang remaja putri. Pengambilan sampel dilakukan secara accidental sampling sesuai dengan kriteria inklusi penelitian yakni mahasiswa putri dan masih semester awal, dengan pertimbangan bahwa semester awal merupakan kelompok usia remaja akhir dan baru memasuki perguruan tinggi, sehingga pajanan informasi terkait gizi dan kesehatan masih terbatas.

Pengumpulan data dilakukan melalui wawancara dengan responden menggunakan kuesioner. Pengukuran variabel meliputi asupan zat gizi dan status gizi remaja putri. Pengukuran asupan energy dan zat gizi menggunakan kuesioner recall 24 jam selam 2 hari. Analisis asupan energy dan zat gizi menggunakan aplikasi nutrisurvey meliputi asupan energy, karbohidrat, protein, lemak, serat, vitamin C, vitaminE, zat besi, seng dan kalsium. Asupan energy dan zat gizi dikelompokkan menjadi kurang apabila asupan $<80 \%$ angka kecupan gizi (AKG) yang dianjurkan bagi remaja. Sementara pengukuran variabel status gizi dengan menggunakan indeks massa tubuh (IMT), lingkar perut (LP) dan lingkar lengan atas (LILA). Kategori obesitas apabila hasil pengukuran IMT $\geq 25$. Sementara kategori kekurangan energy kronis apabila LILA $\leq 23,5 \mathrm{~cm}$.

Analisis data dilakukan secara univariat dan bivariat. Analisis univariat meliputi analisis rata - rata $( \pm$ SD) asupan zat gizi dan status gizi. Sementara analisis bivariat meliputi analisis keterkaitan antara asupan zat gizi dengan status gizi indikator IMT dan LILA pada remaja. Analisis data penelitian menggunakan aplikasi statistic package for social science (SPSS versi 18.0). Uji statistik yang digunakan adalah chi square test. Hubungan antara variabel dikatakan signifikan apabila nilai $\alpha<0,05$.

\section{HASIL}

Hasil pengukuran dari 50 remaja putri menunjukkan bahwa rata - rata umur remaja putrid adalah18,96 tahun, berat badan $52,38 \mathrm{~kg}$, tinggi badan $151,85 \mathrm{~cm}$, pengukuran indeks massa tubuh (IMT) 22,39 , pengukuran lingkar lengan atas (LILA) $26,35 \mathrm{~cm}$ dan pengukuran lingkar perut (LP) adalah $75,90 \mathrm{~cm}$. Rata - rata asupan zat gizi meliputi energy $694,24 \mathrm{kkal}$, karbohidrat $162,77 \mathrm{~g}$, protein $34,31 \mathrm{~g}$, lemak $37,28 \mathrm{~g}$ dan serat 2,07 g. Sementara asupan zat gizi mikro meliputi vitamin C 3,87 mg, vitamin E 1,22 mg, zat besi $3,59 \mathrm{mg}$, seng 1,22 mg dan asupan kalsium 172,93 mg. Analisis kategori asupan zat gizi menunjukkan $100 \%$ asupan energy kurang, 78\% asupan protein kurang, 24\% asupan lemak kurang, 84\% asupan karbohidrat kurang, 100\% asupan serat kurang, 96\% asupan vitamin C kurang, 100\% asupan asupan vitamin E, zat besi dan seng termasuk kategori kurang serta $98 \%$ asupan kalsium kurang.

Gambaran status gizi berdasarkan indikator indeks massa tubuh menunjukkan sebanyak $14 \%$ remaja putri mengalami status gizi kurus, $68 \%$ status gizi normal dan $18 \%$ obesitas. Status gizi berdasarkan lingkar perut menunjukkan 20\% remaja dengan obesitas sentral, sementara berdasarkan indikator lingkar lengan atas $20 \%$ remaja mengalami kekurangan energy kronis (Tabel 3).

Tabel 1. Pengukuran antropometri dan status gizi pada remaja putri 


\begin{tabular}{lcc}
\hline \multicolumn{1}{c}{ Antopometri dan status gizi } & Mean \pm sd & Min-max \\
\hline Umur (tahun) & $18,96 \pm 0,83$ & $16,0-21,0$ \\
Berat badan $(\mathrm{kg})$ & $52,38 \pm 11,82$ & $35,0-87,0$ \\
Tinggi badan $(\mathrm{cm})$ & $151,85 \pm 4,97$ & $141,0-165,0$ \\
IMT & $22,39 \pm 4,46$ & $16,0-38,6$ \\
LILA $(\mathrm{cm})$ & $26,35 \pm 3,51$ & $21,0-38,0$ \\
LP $(\mathrm{cm})$ & $75,90 \pm 8,10$ & $61,0-109,0$ \\
\hline
\end{tabular}

Analisis bivariat menunjukkan asupan kurang protein $15,4 \%$, lemak 16,7\%, karbohidrat 14,3\%, vitamin A 16,1\%, vitamin C 14,6\% dan asupan kalsium 14,3\% dengan status gizi kurus. Asupan kurang protein 15,4\%, lemak 33,3\%, karbohidrat 19\%, vitamin A $12,9 \%$, vitamin C 18,8\% dan asupan kalsium kurang $18,4 \%$ pada remaja putri obesitas. Hasil uji chi square menunjukkan tidak adanya hubungan antara asupan zat gizi baik zat gizi makro maupun zat gizi mikro dengan status gizi berdasarkan indikator indeks massa tubuh pada remaja putrid (Tabel 4).

Tabel 2. Gambaran perbandingan asupan energy dan zat gizi dengan angka kecukupan gizi (AKG) yang dianjurkan pada remaja putri

\begin{tabular}{lccc}
\hline Asupan energy dan zat gizi & Mean \pm sd & Min - max & AKG \\
\hline Energy $(\mathrm{kkal})$ & $694,24 \pm 307,46$ & $230,90-1,464,70$ & 2,125 \\
Karbohidrat $(\mathrm{g})$ & $162,77 \pm 66,34$ & $57,10-318,30$ & 292 \\
Protein $(\mathrm{g})$ & $34,31 \pm 17,36$ & $9,8-104,10$ & 59 \\
Lemak $(\mathrm{g})$ & $37,28 \pm 16,06$ & $14,20-81,00$ & 71 \\
Serat $(\mathrm{g})$ & $2,07 \pm 1,97$ & $0,00-7,50$ & 30 \\
Vitamin C (mg) & $3,87 \pm 8,10$ & $0,00-46,50$ & 75 \\
Vitamin E (mg) & $1,22 \pm 0,89$ & $0,00-3,70$ & 15 \\
Zat besi (mg) & $3,59 \pm 2,84$ & $0,00-11,70$ & 26 \\
Seng (mg) & $1,22 \pm 1,15$ & $0,00-7,60$ & 14 \\
Kalcium $(\mathrm{mg})$ & $172,93 \pm 302,02$ & $0,00-568,00$ & 4,700 \\
\hline
\end{tabular}

Analisis hubungan antara status gizi indikator lingkar lengan atas dengan asupan zat gizi ditunjukkan pada Tabel 5. Remaja yang mengalami kekurangan energy kronis sebanyak 23,1\% dengan asupan protein kurang, 16,7\% asupan lemak kurang, 19\% asupan karbohidrat kurang, 19,4\% asupan vitamin A kurang, 20,8\% asupan vitamin C kurang dan 20,4\% asupan kalsium kurang. Hasil analisis chi square menunjukkan tidak adanya hubungan yang signifikan antara kekurangan energy kronis dengan asupan zat gizi pada remaja.

Tabel 3. Gambaran pengelompokan status gizi dan asupan zat gizi pada remaja putri

\begin{tabular}{lcc}
\hline \multirow{2}{*}{ Status gizi dan asupan zat gizi } & \multicolumn{2}{c}{ Jumlah } \\
\cline { 2 - 3 } IMT & $\mathbf{n}=\mathbf{5 0}$ & $\mathbf{\%}$ \\
$\quad$ Kurus & 7 & 14,0 \\
$\quad$ Normal & 34 & 68,0 \\
$\quad$ Obesitas & 9 & 18,0 \\
LP & & \\
$\quad$ Normal & 40 & 80,0 \\
$\quad$ Obesitas & 10 & 20,0 \\
LILA & & \\
$\quad$ Normal & 40 & 80,0 \\
$\quad$ KEK & 10 & 20,0 \\
Energy (kkal) & & \\
$\quad$ Kurang & 50 & 100,0 \\
Protein (gram) & & \\
$\quad$ Cukup & 11 & 22,0 \\
$\quad$ Kurang & 39 & 78,0 \\
Lemak (gram) & & \\
$\quad$ Cukup & 38 & 76,0 \\
\hline
\end{tabular}




\begin{tabular}{lcc}
\hline Kurang & 12 & 24,0 \\
Karbohidrat (gram) & & \\
$\quad$ Cukup & 8 & 16,0 \\
$\quad$ Kurang & 42 & 84,0 \\
Serat (gram) & & \\
$\quad$ Kurang & 50 & 100,0 \\
Vit A (mcg) & & \\
$\quad$ Cukup & 19 & 38,0 \\
$\quad$ Kurang & 31 & 62,0 \\
Vit C (mg) & & \\
$\quad$ Cukup & 2 & 4,0 \\
$\quad$ Kurang & 48 & 96,0 \\
Vit E (mg) & & \\
$\quad$ Kurang & 50 & 100,0 \\
Fe (mg) & & \\
$\quad$ Kurang & 50 & 100,0 \\
Zn (mg) & & \\
$\quad$ Kurang & 50 & 100,0 \\
Ca (mg) & & \\
$\quad$ Cukup & 1 & 2,0 \\
$\quad$ Kurang & 49 & 98,0 \\
\hline
\end{tabular}

Tabel 4. Analisis hubungan antara asupan zat gizi dengan indeks massa tubuh (IMT) pada remaja putri

\begin{tabular}{|c|c|c|c|c|c|c|c|c|c|}
\hline \multirow{3}{*}{ Variabel } & \multicolumn{6}{|c|}{ Indeks massa tubuh } & \multirow{2}{*}{\multicolumn{2}{|c|}{ Total }} & \multirow{3}{*}{ p value } \\
\hline & \multicolumn{2}{|c|}{ Kurus } & \multicolumn{2}{|c|}{ Normal } & \multicolumn{2}{|c|}{ Obesitas } & & & \\
\hline & $\mathbf{n}$ & $\%$ & $\mathbf{n}$ & $\%$ & $\mathbf{n}$ & $\%$ & $\mathbf{n}$ & $\%$ & \\
\hline \multicolumn{10}{|l|}{ Protein $(\mathrm{g})$} \\
\hline Cukup & 1 & 9,1 & 7 & 63,6 & 3 & 27,3 & 11 & 22,0 & \multirow{2}{*}{0,620} \\
\hline Kurang & 6 & 15,4 & 27 & 69,2 & 6 & 15,4 & 39 & 88,0 & \\
\hline \multicolumn{10}{|l|}{ Lemak (g) } \\
\hline Cukup & 5 & 13,2 & 28 & 73,7 & 5 & 13,2 & 38 & 76,0 & \multirow[t]{2}{*}{0,235} \\
\hline Kurang & 2 & 16,7 & 6 & 50,0 & 4 & 33,3 & 12 & 24,0 & \\
\hline \multicolumn{10}{|c|}{ Karbohidrat (g) } \\
\hline Cukup & 1 & 12,5 & 6 & 75,0 & 1 & 12,5 & 8 & 16,0 & \multirow[t]{2}{*}{0,885} \\
\hline Kurang & 6 & 14,3 & 28 & 66,7 & 8 & 19,0 & 42 & 84,0 & \\
\hline \multicolumn{10}{|c|}{ Vitamin A (mcg) } \\
\hline Cukup & 2 & 10,5 & 12 & 63,2 & 5 & 26,3 & 19 & 38,0 & \multirow[t]{2}{*}{0,461} \\
\hline Kurang & 5 & 16,1 & 22 & 71,0 & 4 & 12,9 & 31 & 62,0 & \\
\hline \multicolumn{10}{|c|}{ Vitamin C (mg) } \\
\hline Cukup & 0 & 0,0 & 2 & 100 & 0 & 0,0 & 2 & 4,0 & \multirow[t]{2}{*}{0,613} \\
\hline Kurang & 7 & 14,6 & 32 & 66,7 & 9 & 18,8 & 48 & 96,0 & \\
\hline \multicolumn{10}{|l|}{ Kalsium (mg) } \\
\hline Cukup & 0 & 0,0 & 1 & 100 & 0 & 0,0 & 1 & 2,0 & \multirow[t]{2}{*}{0,787} \\
\hline Kurang & 7 & 14,3 & 33 & 67,3 & 9 & 18,4 & 49 & 98,0 & \\
\hline
\end{tabular}

Tabel 5. Analisis hubungan antara asupan zat gizi dengan lingkar lengan atas (LILA) pada remaja putri

\begin{tabular}{|c|c|c|c|c|c|c|c|}
\hline \multirow{3}{*}{ Variabel } & \multicolumn{4}{|c|}{ LILA } & \multirow{2}{*}{\multicolumn{2}{|c|}{ Total }} & \multirow{3}{*}{$p$ value } \\
\hline & \multicolumn{2}{|c|}{ Normal } & \multicolumn{2}{|c|}{ KEK } & & & \\
\hline & $\mathbf{n}$ & $\%$ & $\mathrm{n}$ & $\%$ & $\mathbf{n}$ & $\%$ & \\
\hline \multicolumn{8}{|l|}{ Protein $(\mathrm{g})$} \\
\hline Cukup & 10 & 90,9 & 1 & 9,1 & 11 & 22,0 & \multirow[t]{2}{*}{0,424} \\
\hline Kurang & 30 & 76,9 & 9 & 23,1 & 39 & 78,0 & \\
\hline \multicolumn{8}{|l|}{ Lemak (g) } \\
\hline Cukup & 30 & 78,9 & 8 & 21,1 & 38 & 76,0 & \multirow[t]{2}{*}{1,000} \\
\hline Kurang & 10 & 83,3 & 2 & 16,7 & 12 & 24,0 & \\
\hline \multicolumn{8}{|l|}{ Karbohidrat (g) } \\
\hline Cukup & 6 & 75,0 & 2 & 25,0 & 8 & 16,0 & \multirow[t]{2}{*}{0,653} \\
\hline Kurang & 34 & 81,0 & 8 & 19,0 & 42 & 84,0 & \\
\hline
\end{tabular}




$\begin{array}{lccccccc}\text { Vitamin A (mcg) } & & & & & & & \\ \quad \text { Cukup } & 15 & 78,9 & 4 & 21,1 & 19 & 38,0 & 1,000 \\ \quad \text { Kurang } & 25 & 80,6 & 6 & 19,4 & 31 & 62,0 & \\ \text { Vitamin C (mg) } & 2 & 100 & 0 & 0,0 & 2 & 4,0 & 1,000 \\ \quad \text { Cukup } & 38 & 79,2 & 10 & 20,8 & 48 & 96,0 & \\ \quad \text { Kurang } & 1 & 100 & 0 & 0,0 & 1 & 2,0 & 1,000 \\ \quad \text { Kalsium (mg) } & 39 & 79,6 & 10 & 20,4 & 49 & 98,0 & \\ \quad \text { Cukup } & & & & & & \end{array}$

\section{PEMBAHASAN}

Analisis asupan energy dan zat gizi menunjukkan masih rendahnya asupan pada remaja dibandingkan dengan angka kecukupan gizi $(\mathrm{AKG})$. Rata - rata asupan energy adalah $694 \mathrm{kkal}(\mathrm{AKG}=2.125 \mathrm{kkal})$.

Hal ini menunjukkan bahwa remaja putri memiliki kecenderungan mengkonsumsi energy di bawah standar kebutuhan yang berdampak pada renadahnya asupan zat gizi makro maupun zat gizi mikro. Penelitian terdahulu yang dilakukan pada remaja putri di Makassar menemukan bahwa asupan energy kurang $18,1 \%$, asupan protein kurang 33,1\%, asupan lemak kurang 3,1\% dan asupan karbohidrat kurang 46,9\% (Muchlisa dkk, 2013). Asupan energy kurang pada remaja putri juga ditemukan di Bangladesh yakni rata - rata defisit energy $473 \mathrm{kkal}$ per hari, rata - rata asupan karbohidrat $250 \mathrm{kkal}$ per hari dan rata - rata asupan lemak 25 gram per hari, hal ini menggambarkan masih rendahnya asupan remaja dibandingkan dengan AKG (Kabir et al., 2010). Asupan energy yang rendah pada remaja putri akan memberikan dampak negatif seperti kerentanan mengalami kekurangan energy kronis (KEK), anemia, peningkatan risiko melahirkan bayi dengan berat badan lahir rendah (BBLR) saat melahirkan, kerentanan terhadap infeksi dan peningkatan risiko penyakit sindrom metabolik.

Analisis asupan zat gizi mikro menunjukkan masih rendah dibandingkan dengan AKG. Rata - rata asupan vitamin $\mathrm{C} 1,22 \mathrm{mg}(\mathrm{AKG}=15 \mathrm{mg})$, zat besi 3,59 $\mathrm{mg}(\mathrm{AKG}=26 \mathrm{mg})$, seng $1,22 \mathrm{mg}(\mathrm{AKG}=14$ $\mathrm{mg}$ ), kalsium 172,93 mg ( $\mathrm{AKG}=4.700 \mathrm{mg}$ ). Penelitian sebelumnya juga mendapatkan masih rendahnya asupan zat gizi mikro pada remaja diantaranya asupan vitamin $\mathrm{C}$ kurang 92,5\%, asupan zat besi kurang 94,4\%, asupan seng kurang 94,4\% dan asupan kalsium kurang 98,8\% (Muchlisa dkk, 2013)

Penelitian pada remaja putri di Bogor juga mendapatkan 30\% defesiensi asupan vitamin A dan $41 \%$ defesiensi asupan seng (Rosmalina dan Ernawati, 2010). Penelitian di Sri Langka juga mendapatkan masih rendahnya asupan zat gizi mikro pada remaja putri yakni asupan seng yang kurang berpengaruh terhadap kurangnya asupan zat besi 20,5\% dan folat 24\% (Hettiarachchi et al., 2006). Penelitian di wilayah pedesaan India juga menemukan masih banyaknya remaja mengalami defesiensi zat gizi mikro, diantaranya defesiensi vitamin A (97\%), riboflavin (37,8\%), kalsium (43,2\%), zat besi $(10,8 \%)$, vitamin C $(37,2 \%)$. Konsumsi sayur berdaun hijau, buah, kacang - kacangan dan daging - dagingan yang merupakan kelompok makanan sumber zat gizi mikro masih ditemukan rendah pada remaja kelompok subjek penelitian tersebut (Venkaiah et al., 2002). Pada hasil penelitian ini ditemukan adanya kecenderungan asupan zat gizi mikro yang kurang pada remaja obesitas yakni vitamin A kurang 12,9\%, vitamin C kurang 18,8\%, dan kalsium $18,4 \%$. Rendahnya asupan zat gizi mikro pada penelitian ini disebabkan oleh pola makan yang buruk termasuk rendahnya asupan sayur, buah dan produk makanan sumber protein dengan nilai biologis tinggi. Defisiensi zat gizi mikro saat ini telah melingkupi hampir seluruh kelompok populasi manusia dan hal ini akan berdampak buruk terhadap status kesehatan termasuk pada remaja putri (Branca, 2015).

Kecenderungan konsumsi asupan zat gizi mikro yang tidak adekuat akan memberikan dampak negatif bagi remaja, seperti peningkatan risiko penyakit tidak menular, peningkatan angka stunting dan anemia. Negara dengan prevalensi stunting di atas $20 \%$ ditemukan ada keterkaitan yang signifikan dengan asupan zat gizi mikro kurang termasuk diantaranya asupan seng yang kurang (Hettiarachchi et al., 2006). Penelitian di Nepal menyatakan bahwa frekuensi konsumsi sayur - sayuran terutama kelompok sayur berdaun hijau yang kurang berhubungan dengan masih tingginya angka anemia pada remaja putri (Bhandari et al., 2014).

Remaja putri rentang mengalami masalah gizi kurang yang akan berdampak buruk terhadap status kesehatan mereka. Penelitian di Nepal mendapatkan bahwa perempuan yang berusia $15-24$ tahun berisiko 2,7 kali lebih tinggi mengalami gizi kurang dibandingkan perempuan yang berusia 35 - 49 tahun (adjusted odds ratio $\mathrm{aOR}=2,7, \mathrm{CI}=2,5-3,0$ ) (Bhandari et al., 2016). Akibat dari kekurangan energy kronis pada 
remaja putri adalah meningkatan risiko melahirkan bayi dengan BBLR, meningkatkan risiko kematian bayi dan anak, penurunan fungsi mental dan fisik, peningkatan risiko bayi lahir mati dan kematian ibu (Demissie et al., 2003; Black et al., 2013).

Pengukuran status gizi dengan indikator indeks massa tubuh, lingkar perut dan lingkar lengan atas menunjukkan masih adanya sejumlah remaja yang mengalami obesitas dan kekurangan energy kronis. Berdasarkan indikator indeks massa tubuh terdapat $14 \%$ gizi kurang, $68 \%$ status gizi normal dan $18 \%$ obesitas. Berdasarkan pengukuran lingkar perut sebanyak $80 \%$ status gizi normal dan $20 \%$ obesitas. Sementara hasil pengukuran lingkar lengan atas terdapat 20\% remaja mengalami kekurangan energy kronis dan $80 \%$ normal. Jumlah remaja dengan status gizi kurang lebih rendah dibandingkan dengan hasil penelitian di Maros yang menemukan bahwa 34,5\% remaja mengalami gizi kurang (Fanny dkk, 2010). Penelitian lainnya pada remaja putri juga mendapatkan kejadian gizi kurang 33,1\% dan obesitas 5,7\% berdasarkan indikator indeks massa tubuh, sementara sebanyak 35\% dengan kekurangan energy kronis berdasarkan hasil pengukuran lingkar lengan atas (Muchlisa dkk, 2013). Prevalensi gizi kurang pada remaja putri di wilayah pedesaan India adalah 39,5\% (Venkaiah et al., 2002). Sementara penelitian lainnya yang dilakukan di Semnan mendapatkan prevalensi gizi kurang 5,9\% dan obesitas $16,4 \%$ pada remaja putri (Doutmohammadian et al., 2013).

Analisis bivariat menunjukkan tidak adanya hubungan antara asupan zat gizi dengan status gizi remaja berdasarkan indikator IMT. Hasil penelitian ini berbeda dengan penelitian yang dilakukan di Makassar yang mendapatkan bahwa asupan energy dan zat gizi diantaranya energy $(\mathrm{p}=0,000 ; \mathrm{r}=0,495)$, protein $(\mathrm{p}$ $=0,000 ; \mathrm{r}=0,348)$, lemak $(\mathrm{p}=0,002 ; \mathrm{r}=0,244)$ dan karbohidrat $(\mathrm{p}=0,000 ; \mathrm{r}=0,303)$ berhubungan dengan indeks massa tubuh remaja putri, hasil penelitian tersebut juga mendapatkan adanya hubungan antara asupan zat gizi mikro dengan status gizi indikator IMT yakni zat besi $(p=0,001 ; r=0,262)$ dan seng ( $\mathrm{p}=0,000 ; \mathrm{r}=0,356)$ (Muchlisa $\mathrm{dkk}, 2013)$. Analisis bivariat juga menunjukkan tidak adanya hubungan antara asupan zat gizi dengan status gizi indikator LILA. Asupan kurang protein 23,1\%, lemak $16,7 \%$, karbohidrat $19 \%$, vitamin C $20,8 \%$, dan kalsium 20,4\% remaja putri mengalami KEK, meskipun demikian tidak ditemukan adanya hubungan yang signifikan. Hasil penelitian ini berbeda dengan hasil penelitian Muchlisa dkk (2013) yang mendapatkan adanya hubungan antara asupan energy $(\mathrm{p}=0,000 ; \mathrm{r}=$ $0,507)$, protein $(\mathrm{p}=0,000 ; \mathrm{r}=0,407)$, lemak $(\mathrm{p}=0,000 ; \mathrm{r}=0,276)$, karbohidrat $(\mathrm{p}=0,000 ; \mathrm{r}=0,329)$, zat besi $(p=0,000 ; r=0,346)$ dan seng $(p=0,000 ; r=0,398)$ dengan KEK pada remaja. Penelitian lainnya yang dilakukan di India mendapatkan adanya hubungan yang signifikan antara jumlah anggota keluarga, tipe rumah, pekerjaan dan jumlah pendapatan dengan kejadian KEK (Veinkaiah et la., 2002). LILA menurupan indikator yang digunakan untuk mengukur kejadian kekurangan energy kronis. Pada penelitian ini tidak ditemukan hubungan antara asupan zat gizi dengan kejadian KEK, hal ini kemungkinan disebabkan oleh sempitnya waktu yang digunakan dalam pengukuran asupan zat gizi, sehingga belum merepresentasikan pola konsumsi remaja putri pada subjek penelitian. Selain itu, jumlah sampel penelitian yang cenderung sedikit dapat menjadi salah satu faktor penyebab tidak terdistribusinya data secara normal yang berdampak pada hasil perhitungan statistik yang tidak signifikan. Diharapkan pada penelitian selanjutnya akan dilakukan dengan jumlah sampel yang lebih besar dengan pengukuran asupan makanan dilakukan selama beberapa durasi waktu sehingga dapat merepresentasikan kebiasaan dan asupan zat gizi remaja.

\section{KESIMPULAN}

Hasil penelitian ini menyimpulkan gambaran status gizi remaja putri kategori gizi kurus $14 \%$, obesitas $20 \%$ dan 20\% KEK. Analisis bivariat menunjukkan tidak adanya hubungan antara asupan zat gizi dengan status gizi pada remaja putrid akan tetapi remaja putrid cenderung mengkonsumsi zat gizi di bawah angka kecukupan gizi yang dianjurka. Sehingga, upaya intervensi seperti edukasi gizi pada remaja putri menjadi penting dilakukan untuk menambah pengetahuan terkait gizi dan kebutuhan gizi bagi remaja.

\section{REFERENSI}

Arisman. (2004). Gizi dalam daur kehidupan: Buku ajar ilmu gizi. Jakarta: Buku Kedokteran EGC.

Black R.E., Victora C.G., Walker S.P., Bhutta Z.A., Christian P., de Onis M., et al. (2013). Maternal and child undernutrition and overweight in low-income and middle-income countries. Lancet. 382, 427-51.

Bhandari S., Tamrakar J.S., Thapa P., Sayamin M., Kandel B.P., \& Banjara M.R. (2016) Dietary intake 
patterns and nutritional status of women of reproductive age in Nepal: finding from a health survey. Archives of public health. 74(2), 3-11.

Bhandari S., Sayami J.T., Sayami M., Kandel B.P., \& Banjara M.R. (2014). General health status of women of reproductive age in Nepal. J Nepal Health Res Counc. 12,8-13.

Branca F. (2015). Nutrition and health in women, children and adolescent girls. The bmj. 351 (suppl 1),2731.

Demissie T., Mekonen Y., \& Haider J. (2003). Agro-ecological comparison levels and correlate of nutritional status of women. Ethiop J Health Dev. 17,189-96.

Doustmohammadian A., Keshavarz S.A., Sorayya D., Abtahi M., \& Shahani M. (2013). Nutritional status and dietary intake among adolescent girls. Journal of paramedical sciences. 4, 72-77.

Hettiarachchi M., Chadrani L., Rajitha W., David C.H., \& Steven A.A. (2006). Prevalence and severity of micronutrient deficiency: a cross-sectional study among adolescents in Sri Lanka. Asia Pac J Clin Nutr. 15(1), 56-63.

Fanny L., Salmiah, \& Pakhri A. (2012). Tingkat asupan zat gizi dan status gizi siswa SMU PGRI kabupaten Maros Provinsi Sulawesi Selatan. Media gizi pangan. IX (1), 15-19.

Kabir Y., Hussain MS., Farzana S., \& Wahida O.D. (2010). Dietary pattern, nutritional status, anaemia and anaemia-related knowledge in urban adolescent college girls of Bangladesh. J Pak Med Assoc. 60 (8), 633-638.

[Kemenkes RI] Kementerian Kesehatan Republik Indoensia. 2013. Riset Kesehatan Dasar. Jakarta: Kemenkes RI.

Muchlisa, Citrakesumasari \& Indriasari R. (2013). Hubungan asupan zat gizi dengan status gizi pada remaja putri di Fakultas Kesehatan Masyarakat Universitas Hasanuddin Makassar tahun 2013. [Skripsi] Universitas Hasanuddin. Makassar.

Rosmalina Y \& Ernawati F. (2010). Hubungan status zat gizi mikro dengan status gizi pada anak remaja SLTP. Panel gizi pangan. 33(1), 14-22.

United States Agency for International Development. (2015). Nutrition of Adolescent Girls and Women of Reproductive Age in Low- and Middle-Income Countries: Current Context and Scientific Basis for Moving Forward. Arlington : USAID.

World health organization. (2006). Adolescent nutrition: a review of the situation in selected South-East Asian countries. SEA-NUT: New Delhi.

Veinkaiah K., Damayanti K., Nayak M.U., \& Vijayaraghavan K. (2002). Diet and nutritional status of rural adolescents in India. European journal of clinical nutrition. 56, 1119-112. 